\title{
コンデンサ式エックス線裝置（東芝KCD－A型）による 胸部直接擴大撮影について
}

$\left.\begin{array}{clll}\text { (指導 北海道大学医学部放射線科教授 } & \text { 若林 勝博士 } \\ & \text { 立北海道第二療養所長 } & \text { 近藤角五郎博士 }\end{array}\right)$

国立北海道第二療養所

中間光 雄

（論文受付 昭和 31 年 5 月 1 日）

\section{ON THE ENLARGEMENT CHESTRADIOGRAPHY BY THE} CONDENSER DISCHARGE X-RAY APPARATUS

\section{By Mitsuo NAKAMA}

The 2nd Hokkaido National Sanatorium.

(Article recieved : May, 1, 1956)

Summary

By remodeling the anode-earth type condenser discharge X-ray apparatus into a cathode-earth one, the focus for a $10 \mathrm{~kW}$ X-ray tube was reduced by the self bias system. As the focus was magnified by 5 times, changing state of redaction was made elear; microfocus obtained by this method was $0.2 \times 0.3 \mathrm{~mm}^{2}$ in its size.

Exposed time in the radiography was $0.3 \sim 0.5 \mathrm{sec}$. for total discharge was not carried out owing to obstruction of the electron beams due to the grid effect of the bias charge given.

\section{〔I〕緒言}

近時自己バイアス方式によるX線桩大撮影が盛んに行 われるようになったが，それに使用する装置は総て高圧 変圧器方式を用いている。乙れは拡大撮影をするために X線管焦点を微小にするには撮影管電圧とバィアス至適 電圧との関係が定まっており，乙れを行うのに適してい る方法であるからであろう。私は昭和 29 年より蓄電放電 式装置を用いて胸部拔大撮影を行っているが，かなりよ い結果が得られるので茲にその方法を報告する次第であ る.

\section{〔II】拡大撮影に必要な装置の改造}

\section{（1）東芝 KCD-A 型装置}

私の脍部拨大撮影に使用している東芝 KCD-A 型装 置は附図第 1 亿示した構造で，その高圧部分の結線図は 附図第 2 のように陽極接地型であり最高出力電圧 $75 \mathrm{kV}$, 最大出力電流 $1,000 \mathrm{~mA}$ 蓄電器容量 $1.0 \mu \mathrm{F}, \mathrm{X}$ 線管マツダ SDO-10kW である.

(2) 陰極接地型への改造

$\mathrm{X}$ 線管にバイアス電圧を簡単に附加するなめには, 陰 極側を接地した方式か溶易であり且つ又電気的の蜗作も

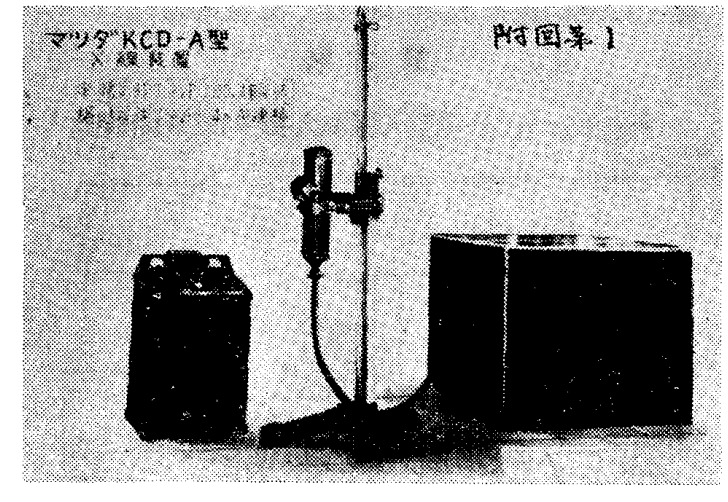

第 1 図

便利であるととから附図第 3 のように結線を変更し陰極 接地方式をとつた。

X線管は陰極側ペースを静かに離脱し，乙れ苍逆に陽 極側に取付けて管球容器内に差込み, 陰極側は一線を管 球容器に, 接地すると共に他の一線と加熱変圧器二次側 に接続した，又電子集束筒に結んであるバイアス電圧を 附加するリード線を引出し十分に絶縁してバイアス電圧 附加装置の陽極側に接続させた.

(3) 改造への考案

一般の变圧器中性点接地方式防電擊診断用装置に桩大 撮影装置を取付ける為には先ずX線管を三極管とし高圧 
ケーブルの陰極側は三荵線にしなければならない。而し て三芯内側線の耐圧は $10 \mathrm{~kW} の \mathrm{X}$ 線管使用の場合, 微小 焦点にするにはバイアス電圧は少なくとも 2,000 万至 $3,000 \mathrm{~V}$ を必要とするし又とれに要する可変抵抗体, 或 いはバイアス電圧用変圧器は高圧回路に挿入しなければ ならないので，一次側との絶縁が十分でなければならな い.このような電気的に困難な問題があるが陰極接地型 にすることにより二次側の耐圧は単に電子集束筒にかか るバイアス電圧 2,000 万至 $3,000 \mathrm{~V}$ のでよい，その他電 気的の操作も非常に簡単になる.

附国第2 蓄電放電式東芝KCD D A 型裝㯰結線目

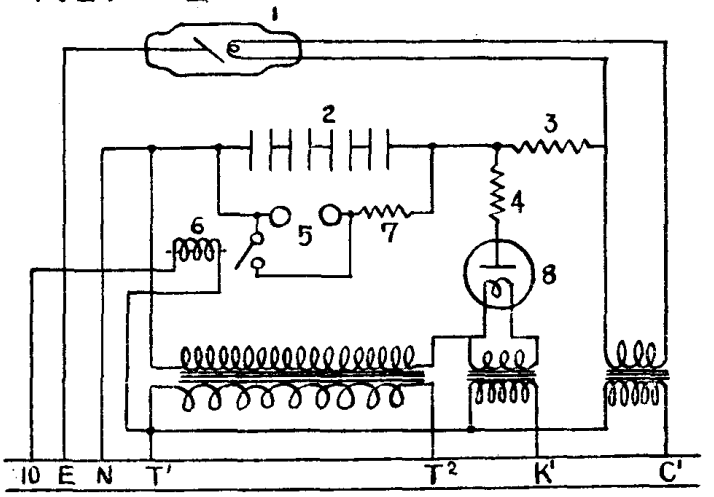

1. X線管 2 . 蓄電器 3. 放電抵抗 4. 充電抵抗 5. 蓄電器過大電圧放電装置 6 . 䄀溜電荷放電装 置 7. 残溜電荷放電用抵抗 8. 整流管

\section{第 2 図}

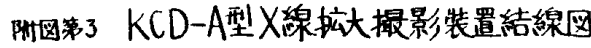

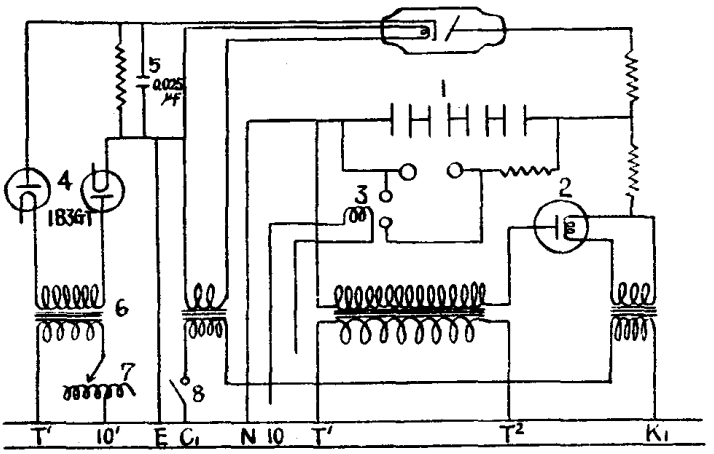

1. 蓄電器 2 . 逆に接線した整流管 3.除去した残溜放 電装置 4.バイアス用整流管 5.バイアス用蓄電器 6. バイアス用変压器 7.バイアス用スライダック 8. 限時装置

\section{第 3 図}

蓄電放電式装置に使用している蓄電器には両極に極性 がなく, 入力電荷の向きを変更しても別に変化はないの で従来のままにしたが陰極を接地するてとによって蓄電 器には陽の高電王が充電されねばならない，そのために 附図第 3 のよう整流管の向きを反対にし, 且つ電流計 の回路も逆にしなければ指針は逆に振る結果になるので
電流計の極を逆に結線変えを行った.

バイアス電圧附加装置は変圧器方式范用い最高二次電 圧 $5,000 \mathrm{~V}$ の変圧器と電圧調節器として $500 \mathrm{~W}$ 型のスラ イダックを用いた，又蓄電放電式装置のためX線管には 完全な直流高電圧が印加されるため，バイアス電圧も直 流にした方か理想的になると考えられるので二次側に整 流管 $1 \mathrm{~B} 3 \mathrm{GT}$ を挿入し脈動直流とし更に $0.025 \mu \mathrm{F}$ の蓄電 器でそれを直流にした。

一般の蓄電放電式装置では限時装置は不必要であるが 拡大撮影装置とした場合は電子集束筒にバイアス電圧を 附加すると陰極電子の走行は抑制され甚だしく管電流は 減少する。このため大電流を通電するととはフィラメン トの熔断や微小焦点の熔解等を来すため不可能であり， 撮影に当っては普通胸部撮影よりかなり高電圧とし一定 時内で撮影して電荷の波尾載断を行うために加熱電流回 路に限時装置を挿入した，又限時装置で電荷の波尾截断 を行うことによって一回の撮影が終るたびに残溜電荷放 電装置が動作するととはわずらわしいので，放電装置を 取除撮影が終って後バイアス電圧莡零に戻し残溜電荷 の全放電を行うことにした。

なお使用したマツダ SDO-10W X線管は市販のもの のうちから使用前に電子集束筒より出ているリード線と フィラメント加熱リード線との間の耐圧試験を行い耐圧 約3,000Vのものを用いたのである.

\section{〔IIII 微小焦点の攝影及面掼の測定}

\section{[A] ピンホールカメラに依る方法}

(1) ピンホールカメラの製作

ピンホールカメラの長さは $30 \mathrm{~cm}$ として右図のような

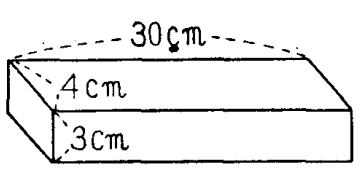
鉛角筒を作った。

ピンホールに用いる鉛板の 厚さは描写される焦点の大き さに誤差を生ずる一つの原因 になるが，あまり厚くすると極く小さいピンホールを作 ることが出来ず，又薄くすると鉛板をX線が透過してフ ィルム自体を感光させてしまう結果となる．そてで撮影 電圧を $60 \mathrm{kV}$ として焦点撮影に可能な鉛板の厚さ約 0.6 $\mathrm{mm}$ 程度のものを用いた。

ピンホールの大きさについては1)一般病院では0.1mm 以下の穴を開けることは困難とされているが，私は前述

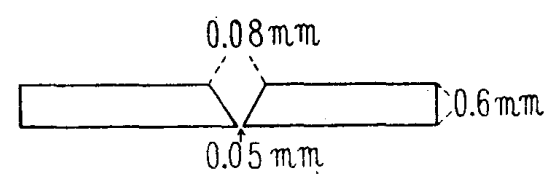

の鉛板に極く細 かい槰針で右図 のような約 0.05 $\mathrm{mm}$ の大きさの 
穴を開けることが出来た。

穴の大きさは顕微鏡で測定したのであるが針の先で開 けたピンホールは円形ではあるが正確なものではなく又 一寸した強い摩擦によっても誤差を生じてくる.

(2) 焦点の撮影法とその結果

焦点の実大撮影と拡大撮影を行った。実大撮影山昭和 30 年 8 月 X線管の取付け時に行ったものであり, 拡大撮 影は取付け 7 力月後行行ったもので対称比較するてとは 出来ないが一応その方法を述べるととにする。

イ）微小焦点の実大撮影

撮影条件: $60 \mathrm{kV}, 2 \mathrm{~mA}, 4 \mathrm{~min}$.

撮影距離 : $30 \mathrm{~cm}$ (焦点, ピンホール間) $-30 \mathrm{~cm}$ (ピン ホールフィルム間)

附加バイアス電圧 : $0,500,1,000,1,250,1,500,1,750$ $2,000,2,250,2,500 \mathrm{~V}$

次ぎに傾斜角度をつけて：1,750V約 18 度

撮影結果 : 附図第 4 のようになった

口）微小焦点の 4 倍拡大撮影

撮影条件: $60 \mathrm{kV}, 2 \mathrm{~mA}, 4 \mathrm{~min}$.

撮影距離 : $7.5 \mathrm{~cm}$ (焦点, ピンホール間) $-30 \mathrm{~cm}$ (ピン ホールフィルム間)

附加バイアス電圧 : $0,500,1,000,1,250,1,500,1,750$

$2,000,2,250,2,500 \mathrm{~V}$

次傾斜角度をつけて：1,750V 約 18 度

撮影結果 : 附加第 5 のようはなった。

焦点写真像の濃度は焦点の状態を観察するのに都合の よい2）最高黒化度を 1.2 1.5 亿止めた。

附四第 4 微小焦点の実大撮影写真 $(60 \mathrm{kV})$

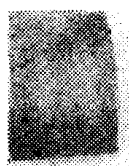

0

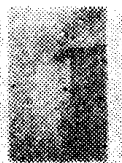

500

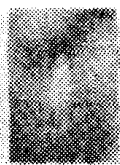

1000

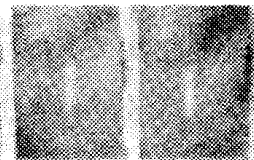

1250
1500

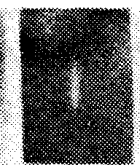

1750

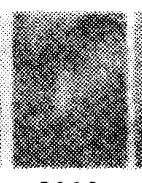

2000
（3）小括並びに考案

実験結果附図第 4 亿よるとバイアス電圧を上昇するに つれて $(0 \sim 1,500 \mathrm{~V})$ 焦点の横门は狭められるが縦の長 さは殆んど変化なくバイアス電圧 $2,000 \mathrm{~V}$ 附近より䅠の 長さは縮まってくるが，逆借门は広がっくる状熊が認 められる. 又 $1,750 \mathrm{~V}$ の約 18 度の傾斜により焦点は略々 点と看做される程度に縮少されるが何分にも写真像は小 さく正確に焦点の縮少されていく状態を知ることは出来 ず概略の傾向を知るに過ぎない。

実験結果附図第 5 の微小焦点 4 倍拡大撮影写真像によ って10kW 規格の焦点がバイアス電死附加によって, 微 小焦点へ移行していく状㦔，大きさ等を容易に観察する ことが出来た。

この 4 倍拡大写真像から焦点の状態を考察すると，バ イアス電圧 $0 \mathrm{~V}$ の場合は $10 \mathrm{~kW} 5 \times 5 \mathrm{~mm}$ 焦点の約 4 倍に なっている。即ち面積は約16倍に搪大されているてとに なる. この写真像によると焦点は平滑のようであるが, このX線管で既に 3,500回以上の胸部撮影を行っている ので実際に焦点を肉眼で見ると, 中央附近潢に刍裂が あり少し，凹凸になっているし焦点面もかなり粗雑にな っているが拡大によって，か光っててれ等が目立って見 えない，てれにバイアス電圧を除々に加えていくに従っ て焦点の横巾は急激に狭まっていくが繸の長さはさ程変 化しない，又横巾の狭まり方は焦点の電子密度の大きい 両側少ら平行に狭まらず，ある程度 $\mathrm{V}$ 状になって狭まっ てくる，てれはフィラメントに対して焦点は平行ではく 約19度の傾斜があるために，焦点とフィラメント間の距

髉の違いが及ぽす 影響であろうと考 える. 即ち距離の 近い方が低いバイ アス電子は集束さ れ遠くになるにつ れて高いバイアス 電圧を要するもの と思われる. 又バ イアス電圧 $0 \mathrm{~V} の$ 場合は焦点の鮡裂 や粗雑な状態が桩 大によってかっっ て不明瞭であった が, バイアス電压 存上昇さすに従つ て亀裂の状態は八 
ッキリと溝が出来て遂には焦点を二分したようになるが， これは焦点の渑裂部分の面に電子が集束されていったか らで焦点中央部の面が亀裂や粗雑になっていることは拡 大撮影には特に支障がある。

バイアス電圧 1,500 1,750V 附近は大した変化はなく 焦点のV 型の状態か増々その度を縮めて中央に線状の核 のような電子の強く集束されたとてろを見受け，その周 围を稀薄なX線像が包んでくる，乙の状態はV状の電子 集束が一点に結ばれたところに至って現れてくるのであ るが，電子は平行状態の集束には遂にならずV状集束が 極度に瘗った部分から急電子は稀薄な抬散状態に移行 していくが，これは微小焦点のバイアス至適電圧以上に 加えられたら，電子は急に拡散の状態をとる現れである と考えられる。

バイアス電圧 1,750 ～ $2,000 \mathrm{~V}$ 亿なると電子は殆んど中 央に狭められV状のわれ目はようやく識別される程度と なる一方逆に拡散に入った部分が見受けられる。この附 近が $60 \mathrm{kV}$ 亿於ける拡大撮影に用いるバイアス至適電圧 であろう.

バイアス電圧 $2,000 \mathrm{~V}$ では電子は中央に集束されて細 い線状となると共に㧨散状熊の現れである．周用の稀薄 像が目立ってくる.

バイアス電圧 $2,250 \mathrm{~V}$ ではこれまであまり変化のなか つた焦点の縦の長さが急に縮少されて来た。

バイアス電圧 $2,500 \mathrm{~V}$ 亿至ればも早焦点の中央の電子 密度の強い線によるX線状核は全く消失し縦の長さの短 縮された一様な抬散した焦点像となっていまう。斯くな ると管電流は非常に流れ難くなり ${ }^{3)}$ 第 1 表のように加熱 電流を遙かに上昇させ祆ば所要の管電流を得るととが出 来なくなる。

第|表 バイアス電圧と管電流の関係

\begin{tabular}{|c|c|c|c|c|c|c|}
\hline 管電流 & 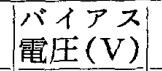 & 0 & 500 & 1,000 & 1,250 & 1,500 \\
\hline $2 \mathrm{~mA}$ & 加熱電流 & 3.1 & 3.15 & 3.20 & 3.30 & 3.40 \\
\hline
\end{tabular}

撮影を行う場合の管電圧 $60 \mathrm{kV}$ ではバイアス至適電圧は $1,750 \mathrm{~V}$ と決めた。

焦点の縦の長さを縮少さすために一般にX線管焦点を 平行に傾斜させているが約18度倾斜した附図第 4 の場合 は略々点点々看做してよいが，附図第 5 の拡大写真像で は焦点の角裂のため傾斜させても 1 点には結ばなかつ た。これは亀裂によって焦点面は平滑を欠き刍裂面を境 して凹凸となり如何に焦点面を平行においてみても焦点 全面汃水平面になるものではなく，てれがたる焦点は分
離した点となって現われ，実際の胸部拡大撮影にも焦点 の新しい時よりもよい結果が得られなかったてとから刍 裂は昖大撮影にとっては直接撮影よりも大きく写真上に 鮮鋭度を害する原因となるようである。

\section{[B] 解像力による方法}

(1) 撮影に用いた金網

解像力による微小焦点の大きさを測定する方法とし て1) 一般に $0.05 \mathrm{~mm} \sim 0.1 \mathrm{~mm}$ 程度の細い針金を針金の太 さと同じ間隔に並べて拡大撮影を行い，その解像力の限 界から焦点の大きさを測っているが，私は市販の細かい 金網を被写体として撮影し，乙の解像力加ら焦点の大き さを推測してみた。

即ち市販の $200,150,100,50 \times ッ シ ュ の 4$ 種類の金 網を用いた。（註,メッシュとは 1 时の間にある目数を (5)

この金網をマイクロホトメーターで測定して見たら 200 メッシュは針金の太さが約 $0.04 \mathrm{~mm}$ で目の広さ(間隔) は約 $0.081 \mathrm{~mm}, 50$ メッシユは針金の太さ約 $0.06 \mathrm{~mm}$ で目 の広さは約 $0.11 \mathrm{~mm}, 100$ メッシユは針金の太さ約 0.07

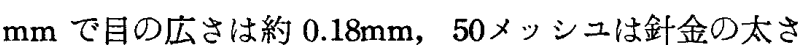
は約 $0.1 \mathrm{~mm}$ で目の広さは約 $0.38 \mathrm{~mm}$ の間隔であった。

(2) 撮影方法及び結果

4 種類の金網をそれぞれ約 $0.5 \mathrm{~cm}$ ，長さ約 $35 \mathrm{~cm} に$ 切り 厚紙に平行に貼付け大陸判フィルムに撮影して作用焦点 のX線強度分布汃らくるフィルムの黒化度の変化之解像 力との関係を調べた。

1）撮影距離 : $75 \mathrm{~cm}$ (焦点金網間) $-75 \mathrm{~cm}$ (金網，フ イルム間)

口）撮影条件 : $60 \mathrm{kV}, 2 \mathrm{~mA}$.

八）密着撮影をして次に 2 倍拡大撮影に距離をとり附加 バイアス電圧を $0 ， 500 ， 1,000$, $1,250,1,5000,1,750,2,000$, $2,250,2,500 \mathrm{~V}$ として撮影. $\Rightarrow$ 撮影結果は附図第 6 のように なった。

(3) 小括並びに考案

撮影に使用したX線管は焦点に龟裂のあるものを用い たので新しいX線管よりは解像力も劣っているに違いな いが 2 倍拡大撮影によってどの程度まで細かい金網が解 像されるかについて実験したのである。

撮影した金網のうち200，150メッシュのものは金網の 針金の太さと目の一辺の長さとの割合は約 $1: 2$ で 100

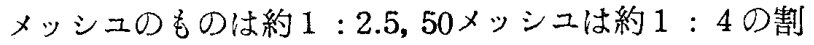
合である. 撮影結果の附図第 6 は大陸フィルムに撮影さ 


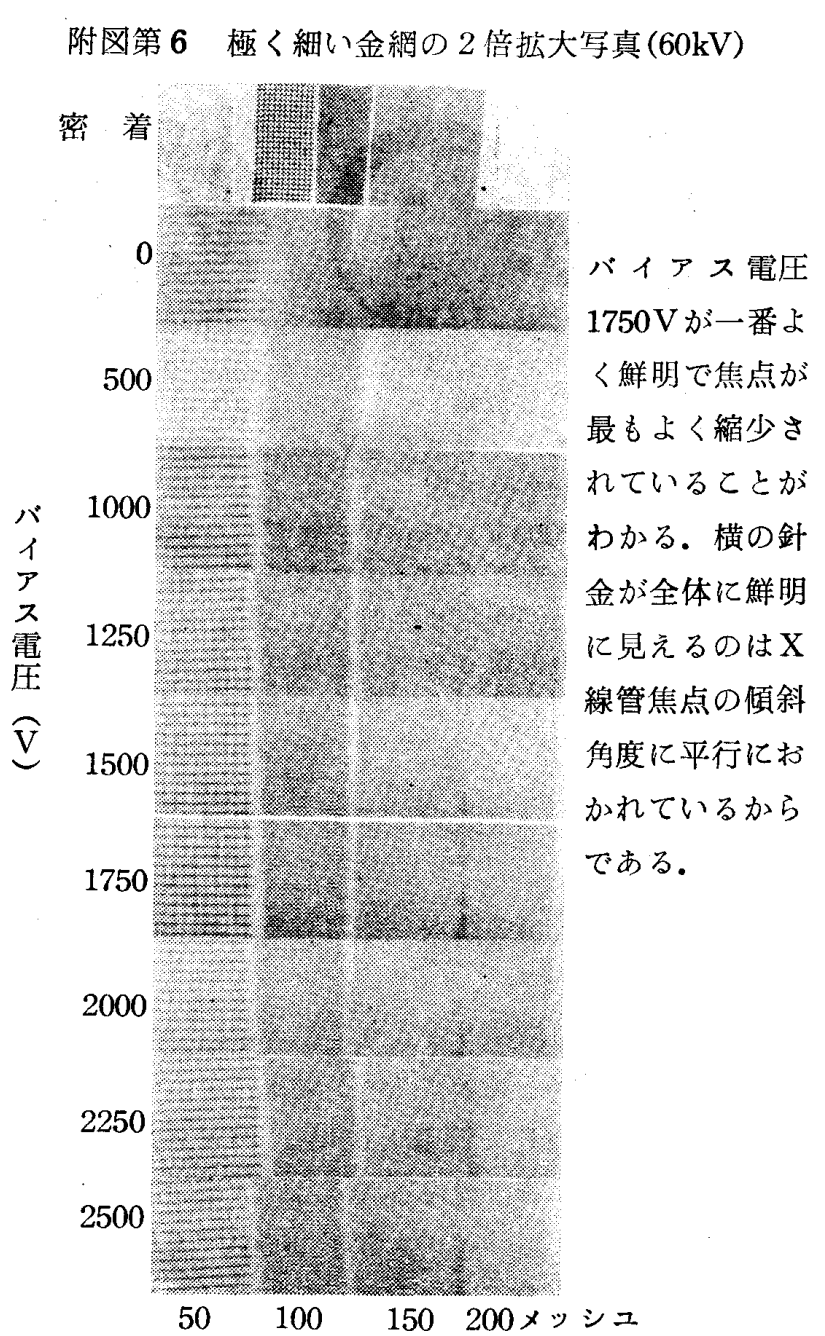

れた金網像のうち X線强度分布が平均化し黒化度が一定 して来た部分をカットしたものであるが附加バイアス電

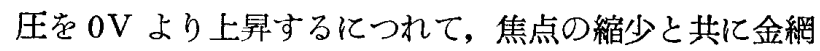
の目もハッキリして来た， $1,500 \sim 2,000 \mathrm{~V}$ 附近がよく解 像されているようである, 特に $1,750 \mathrm{~V}$ はハッキリして $200 \times ッ シ 二 の$ 金網もようやく解像されている，2,000V

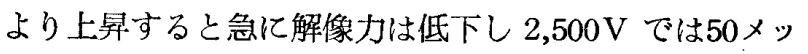
シュの金網ですら朦朧として来た,

ての解像力の観察とピンホールによる焦点の 4 倍拡大 写真とを比較して見ると, 大体パイアス電圧 $1,700 \mathrm{~V}$ 附 近が使用した S D O-10kW X線管の微小焦点に 必要な バイアス至適電圧であろうと思われた。

$\mathrm{X}$ 線搪大撮影飞バイアス電圧附加によって10kW X線 管を用いることは焦点の横巾はバイアス電圧によつてあ る程度 $\mathrm{V}$ 状集束ではあるが，自由に狭く出来るが縦の長 さはそれ程変化なく，X線管の傾斜によって無理に作用 焦点を小さくするが $10 \mathrm{~kW} \mathrm{X}$ 線管は焦点の縦の長さは 約 $10 \mathrm{~mm}$ もあり，バイアス電压によって少しは短かくな るとしても小焦点X線管にバイアス電圧をかけ微小焦点
にしたよりもフィルムに鮮鋭な像を結ばせる範囲は狭め られる. $10 \mathrm{~kW} \mathrm{X}$ 線管の場合 2 倍拡大撮影を焦点フィル 么間距離を $150 \mathrm{~cm}$ で撮影した金網の縦の針金は一定の太 さであるが，横の針金は角度がつくに従って太くボケて くるが肉眼的にフィルム上で鮮鋭に見られる長さは約 $15 \mathrm{~cm}$ の範囲であり，ての場合焦点平面よりなす角度は 約 5 度程度までのとてろである，

\section{[C] 徽小焦点の大きさ}

微小焦点の大きさの測定を焦点の 4 倍桩大写真像より 考察すると，微小焦点の横巾は平行に狭まるすのでなく 或る程度 $V$ 状になって縮小され, 然してての電子集束の V状の頂点は交攴するのではなく直ちに拡散に移る。こ れでは正確にバイアス至適電圧を決定するには困難であ る. 又焦点の縦の長さもX線管を傾斜させ無理に縮少投 影さす関係でフィルムに対して或る一部分にはたしかに 縦横の二次元共に線と看做されそれが投影されて点とな るが全面的には点とならない．それで大凡の焦点の大き さでフィルムに投影された一部分の鲜鋭像のとてろから 推測決定することになる。附図第 5 の管電圧 $60 \mathrm{kV，バ}$ イアス電圧 $1,750 \mathrm{~V}$ 傾斜角度約 18 度の写真像では絴横共 に狭まり;累積状の不整形ではあるが大体点と看做し,て れから焦点の大きさを推測してみるとみると焦点周辺部 の稀薄な濃度の部分は一般にX線写真像には影響されな い部分であり，ボケの原因を無視してよいとされている ので従って電子密度分布の強い高浱度部分の中心核雨辺 の最大值陰影を計測したら横約 $1.2 \mathrm{~mm}$, 縦約 $1.3 \mathrm{~mm}$ で あった. てれを四分の一にしてその数值を1) 焦点測定公

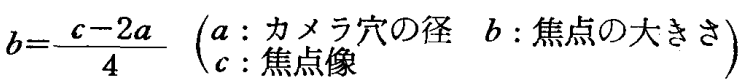
式に代入して計算したら約 $0.29 \mathrm{~mm}$ 微小焦点となった。

又極く細かい金網を拡大撮影してその解像力より微小 焦点の大きさを推測すると附図第6のバイアス電圧 1,750 Vの写真では 200 メッシュの金網も解像されている。そ こで 3 倍拡大撮影ではどのようになるかを管電死 $60 \mathrm{kV}$ バイアス電圧 $1,750 \mathrm{~V}$ で撮影した結果は附図第 7 のよう に200メッシュの金網がようやく解像されているとてろ から, てれがての焦点で撮影する解像力の限界と考元4 これから微小焦点の大きさを求める公式

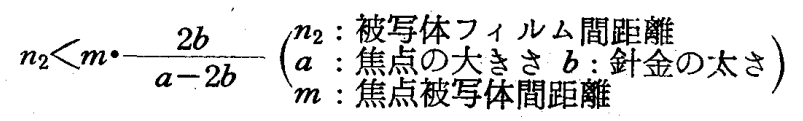

に代入して計算した結果は

$$
1000<500 \times \frac{2 \times 0.04}{x-2 \times 0.04} \quad x<0.12 \mathrm{~mm}
$$

の数值が出た。これは針金の太さと等間隔に並べた被写 体を撮影した場合であるから 200 メッシュの針金の太さ 
は約 $0.04 \mathrm{~mm}$, 間隔は約 $0.08 \mathrm{~mm}$ で約 2 倍の広さがあるの

で計算值 0.12 を 2 倍したら $0.24 \mathrm{~mm}$ の数值となった。

附図第 7 金網の 2 倍拡大撮影写真 $(60 \mathrm{kV} 1750 \mathrm{~V})$

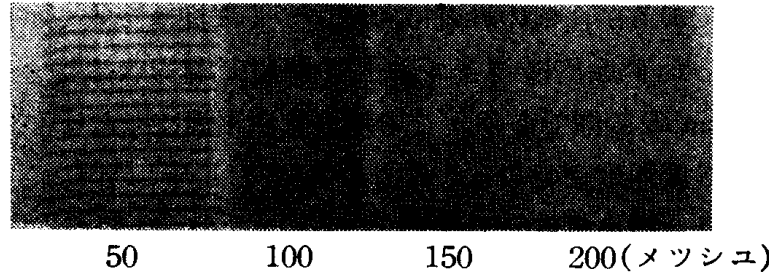

$200 \times$ メュの金網もようやく解像されている。

の附近が使用した微小焦点の解像力の限界であろう。

微小焦点の 4 偣抾大写真像の結果からは約 $0,29 \mathrm{~mm}^{2}$ の 微小焦点となり，200メッシュの細い金網を撮影した場 合は約 $0.24 \mathrm{~mm}^{2}$ の微小焦点となったが大体 $0.2 \mathrm{~mm}^{2} \sim 0.3$ $\mathrm{mm}^{2}$ の範囲の微小焦点のように考へられる。しかしこれ はフィルムに投撮された像の一部分のところを論したの であって直接撮影のように大陸判フィルムの全般的に及 ぼす鮮鋭度を決定するものではない。その測定した部分 より上方に向うにつれて鮮鋭度は悪くなり，下方になる につれ鮮鋭度はよくなってくる.

使用したX線管は $10 \mathrm{~kW} て ゙$ 然かも焦点面の刍裂が障碍 し極微小な焦点にはなし得なかったように思われるが, この程度に胸部の 2 部拡大撮影を部分的に行い彰断可能 なX線写真を撮っている。

\section{[IV]管電圧の変化とバイアス至適西 圧との関係}

撮影する管電任こそれに附加するバイアス至適電圧と の関係は定まっているので5)，管電压を変化させば当然 バイアス電圧もそれに伴って変化させねばならないが, 蓄電放電式装置では撮影中常に管電圧が変化してくるの でそれに対するバイアス至適電圧を調べてみた。

(1) 実験方法及びその結果

イ） $50 \mathrm{kV} 2 \mathrm{~mA} 4$ 倍拡大 付加バイアス $125015001750 \mathrm{~V}$

ロ） $55 \mathrm{kV} 2 \mathrm{~mA}$ 4谙抎大附加バイアス $125015001750 \mathrm{~V}$
附図第 9 遮蔽グリット效果による蓄電器残溜 電荷の実験

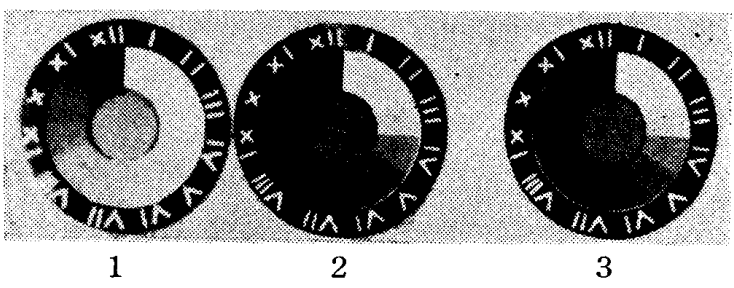

1. $65 \mathrm{kV}, 2000 \mathrm{~V}$ で放電

2. 放電後直ちにバィアスを $0 \mathrm{~V}$ にて残溜電荷全放電 3. $45 \mathrm{kV}$ 充電で全放電

$65 \mathrm{kV}$ ，バイアス $2000 \mathrm{~V}, 25 \mathrm{~mA}$ で放電した場合, $45 \mathrm{kV}$ 附 近まで電圧が降下したらパイアス電圧の遮蔽グリット効 果によつて電流は抑制阻止されることは, その残溜電荷 と $45 \mathrm{kV}$ 電荷の全放電とをべノア硬度計で比較したら濃 度が大体一定していることでわかる。

八） $60 \mathrm{kV} \quad 2 \mathrm{~mA}$ 4倍拡大 附加バイアス 15001750 $2000 \mathrm{~V}$

） $65 \mathrm{kV} \quad 2 \mathrm{~mA}$ 4倍拡大 付加バイアス 12501500 $1750 \mathrm{~V}$

ホ）撮影結果は付図第 8 のうになった。

(2) 管電圧の降下と遮槆グリット効果

蓄電器容量 $1.0 \mu \mathrm{F}$ で管電在 $65 \mathrm{kV}$ ，バイアス電圧 $0 \mathrm{~V}$ として管電流 $25 \mathrm{~m}$ Aを通電した場合は放電時間は長いが 全放電する.しかしバイアス電圧 $2000 \mathrm{~V}$ を付加したら 或る一定の管電圧までは放電を行うがバイアス電圧によ る遮蔽グリット効果によって電子の走行は抑制され管電 流は殆んど流れなくなり自然的に管電圧の波尾截断が行 われることになる。

いま管電圧 $65 \mathrm{kV}$, バイアス電压 $2000 \mathrm{~V}$ ，管電流 $25 \mathrm{~mA}$ の通電で管電圧がどれだけ降下したら遮蔽グリット効果 によって電流が流れなくなるが旁べノア硬度計で実験し た。

実験(1) 管電圧 $65 \mathrm{kV}$,バイアス電圧 $1750 \mathrm{~V}$, 管電流 $25 \mathrm{~mA}$ で放電後直ちに残溜電荷をバイアス電圧を $0 \mathrm{~V}$ 亿戾して 放電してベノア硬度計の濃度を調べたら付図第 9-1.2の ようになった。

附図第 8 管電圧の変化とバイアス至適電圧との関係

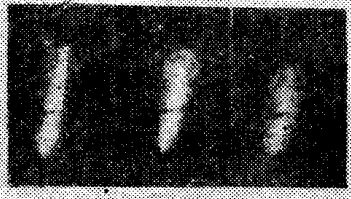

$1250 \quad 1500 \quad 1750$ $50 \mathrm{kV}$

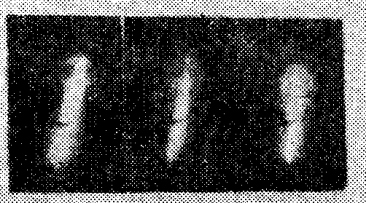

$1250 \quad 1500 \quad 1750$

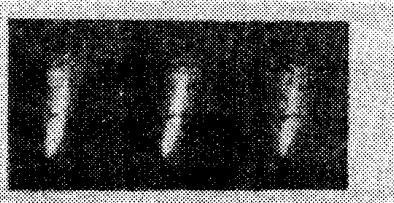

1500 $55 \mathrm{kV}$

$1750 \quad 2000$ $60 \mathrm{kV}$

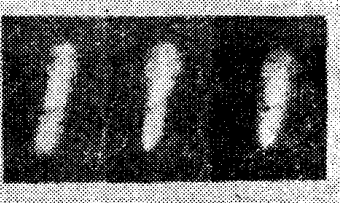

$1500 \quad 1750 \quad 2000 \quad(\mathrm{~V})$ $65 \mathrm{kV}$

管電圧の上昇と共にバイアス至適電压も上葘することがわかる $50 \mathrm{kV}$ では $1500 \mathrm{~V} 65 \mathrm{kV}$ では $2000 \mathrm{~V}$ 附近 が至適電圧であらう。 
実験(2) 管電圧 $4.5 \mathrm{kV}$ ，バイアス電压 $0 \mathrm{~V}$ ，管電流 $25 \mathrm{~mA}$ で全放電を行ったらその結果は付闵第 9-3 のようにな った。

との結果から管電圧 $65 \mathrm{kV}$ で管電流 $25 \mathrm{~mA}$, バイアス 電圧 $2000 \mathrm{~V}$ を附加すればバイアス電圧の遮蔽グリット 効果によって管電圧が $45 \mathrm{kV}$ に降下すれば管電流は流れ なくなることがわかった。

(3) 小括並びに考按

効電生の相違によってバイアス至適電圧と又変ってくる てとはこれまでに(1)5)詳紼に報告されているが，私は自 分の使用するX線管の概略の特性を知るために実験立行

オ2表管軋压とバイアス至適電压

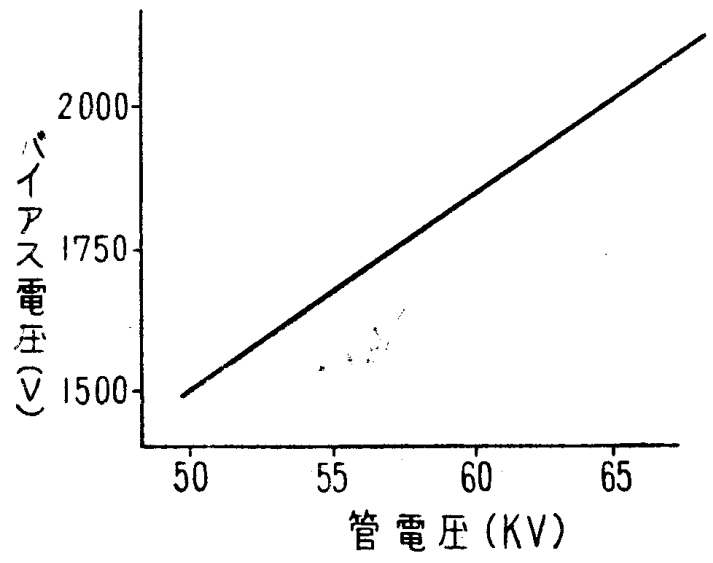

つたが付図第 8 から各管電圧のバイアス至適電圧は第 2 表のような特性のあることを知った。即ち管電圧の上昇 と共にバイアス至適電圧も上开する。

蓄電放電式では撮影する管電圧は充電々圧（放電最高 電纴）を頂点として降下するが，バイアス至谪電圧は充 電々压に合せたまま依然として変化さすことは出来な い.しからばどの程度管電圧が降下したらバイアス電圧 による遮蔽グリット效果で電流の仰制が行われるかを(2) の実験 1.2 によって調べたのであるが付図第 9-1 はべ ノア硬度 8 9 度であり 2 はベノア硬度 4 付近である. 又実験 2 も大体同一の硬度であるところから管電圧 $45 \mathrm{kV}$ 付近で管電流は抑制阻止されたものと考えられる。しか し私達は蓄電放電式装置で胸部撮影を行う場合成人胸厚 $18 \mathrm{~cm}$ の被写体では管電圧 $45 \mathrm{kV}$ 以下に降下した軟X線 は胸部組織で殆んど吸収されフイルムに黒化を与えない。 しかも放電々压の最高部分の電荷で殁んど撮影は完了さ れているため，撮影に当ってバイアス至啇電圧は正確で はないが充電々圧に合せておいてよいことになる，バイ アス至谪電圧は撮影管電圧に対して絶対的のものではな く, ある程度の範囲のあるととは微小焦点の撮影の項で
述べたが私は一般胸部拡大撮影の場合管電圧は 60ー70 $\mathrm{kV}$ としててれに対してバイアス至適麗任は $1750 \mathrm{~V}$ $2000 \mathrm{~V}$ にして行っている.

(9)ハイアス電圧を $6000 \mathrm{~V}$ 以上高電在とした場合は焦 点は縦横共に完全に微小となりこれが拡大撮影に最も適 したバイアス至適電圧と言われているが。このようなバ イアス高電圧を付加すると管電流は非常に抑制されてお びただしく加熱電流を上昇させねばならないのでX線管 にはますます無理な使用法となり，且つ又小電流のため 管電圧を甚だしく高電圧にしなければなら䛀ととから現 在一般の診断用装置を使用した場合の拡大撮影は此の方 法では不可能のように思われ，私はバイアス至適電圧を 低いとてろで求めて拡大撮影を容易に行っている。

\section{〔V〕抎大摄影時間}

微小焦点にすればX線管の性質上どうしても大電流, 瞬間撮影は出来ない，当然小電流，時間撮影となる，蓄 電放電式で管電圧 $65 \mathrm{kV}$ バイアス電圧 $2000 \mathrm{~V}$ を付加し 管電流 $25 \mathrm{~mA}$ の通電では放電にかなり時間を要するので 限時装置による電荷の波尾截断を行った。

（1）限時装置の取付

附四第10入線管加熱回路下押入i太限時裝置
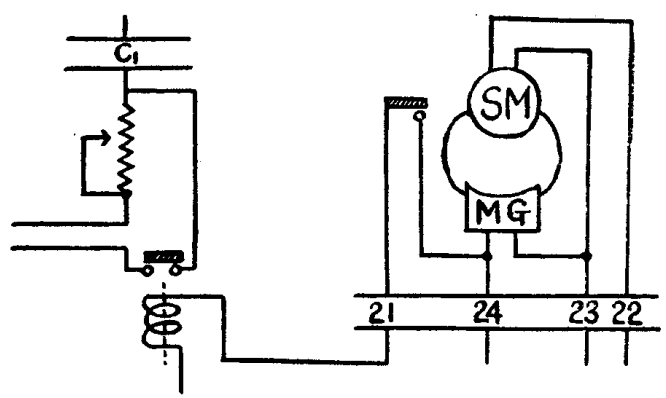

限時装置の取付けは付図第 3 の加熱回 $C_{1}$ 路に付図第 100ように東芝型夕イマーを挿入したが，東芝 $\mathrm{KCD}-\mathrm{A}$ 型装置はフィラメント点加方式であるため加熱スイッチ 哇入れれば直ちに限時装置は動作するが管電流はフィラ メントの予熱時間を経て始めて流れる。 そのため限時装 置にはとの予熱時間が含まれる。

(2) 撮影時間の測定

管電生 $65 \mathrm{kV}$ ，バイアス至適電在 $2000 \mathrm{~V}$ 亿於いて限時 装置が動作してフイラメント予熱時間を経て始妨て所定 の管電流 $25 \mathrm{~mA}$ の電流が流れ放電が終了時間を限定し た.

1) ベノア硬度計による測定

先ず撮影スイッチを入れてフィラメントの予熱から撮 影有效の加熱になるまでの時間を測定するために管電瓜 
$65 \mathrm{kV}$ ，バイアス電圧 $2000 \mathrm{~V}$ ，管電流 $25 \mathrm{~mA}$ ，距離 $150 \mathrm{~cm}$ でベノア硬度計を用い 0.1 秒から 0.5 秒までの間を 0.1 秒間隔で撮影した結果は付図第11-1のようにに大体 0.3 秒の遅れのあることを知った。

附図第11 撮影時間の測定（A）

(1)

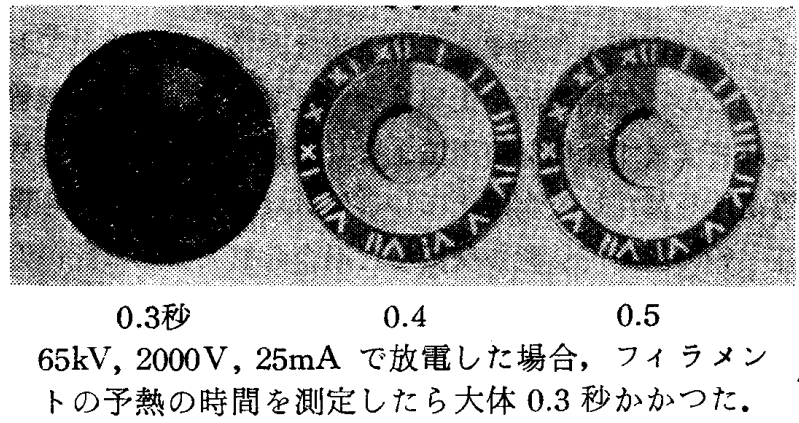

(2)

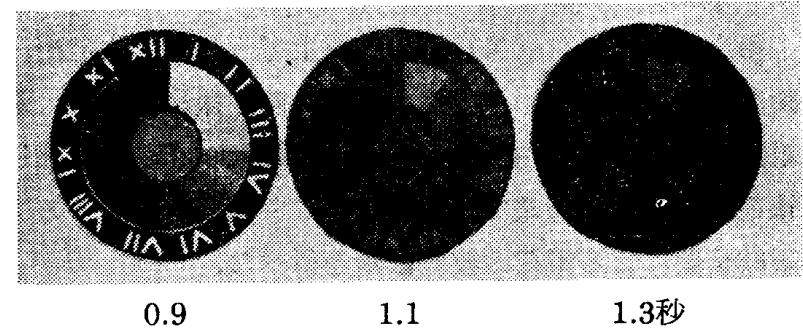

放電後バイアス電压はそのままで放電可能な残溜電 荷がどの程度あるかる調べたら 1.3 秒でべノア硬度 計にようやく感光する程度になつた。とのてとから 大体 0.3 秒から 1.3 秒の約 1 秒間放電が行なわれて いることがわかる。

又どれだけの放電持続時間があるかを知るため 0.5 秒 より 1.3 秒までの間を 0.2 秒間隔に放電後バイアス電圧 を付加したままの残溜電荷を放電させべノア硬度計を撮 影してみたら残溜電荷は 1.3 秒のところで付図第11ー2 のようにべノア硬度計がかすかに撮影されている，この 結果からバイアス電圧を付加したままで放電した場合限 時装置の目盛の上では 0.3 秒のとてろから 1.3 秒までの 約 1 秒間のうちに放電さ机ている.

口）胸部拡大撮影による測定

次ぎに成人䏩厚約 $18 \mathrm{~cm} の$ 胸部拡大撮影管電圧 $65 \mathrm{kV}$ バイアス電圧 $2000 \mathrm{~V}$, 管電流 $25 \mathrm{~mA}$, 距離 $150 \mathrm{~cm}$ にして 0.2 秒上り 1.2 秒まで 0.2 秒間隔で撮影を行い黒化度の 変化加有效撮影時間を求めた絬果は付図第120ように 0,4 秒付近より撮影が開始され 1.0 秒付近よりは大して 黒化度は增していない。

(3) 小括注びに考案

この実験から蓄電放電式装置による拡大撮影には限時 装置は必装であることがわかる，即ちべノア硬度計によ る測定では 0.3 秒から 1.3 秒の間に於てフィルムに感光
附図第12 撮影時間の測定（B）

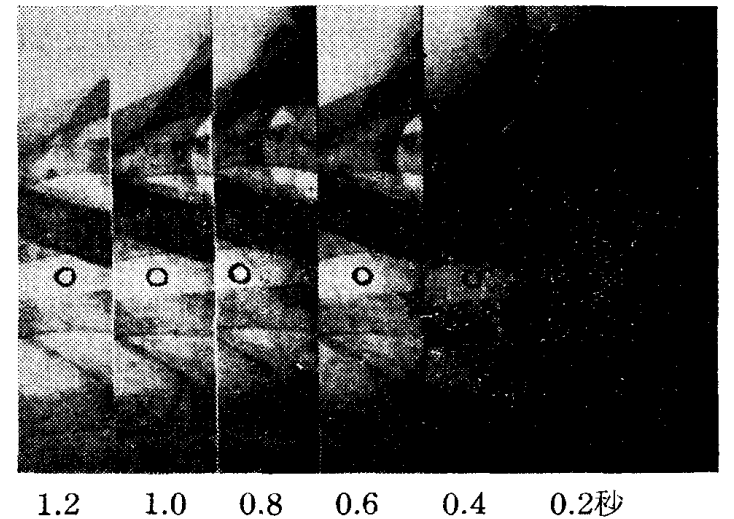

胸厚 $18 \mathrm{~cm}$ の成人を摄影したら 0.4 秒から 1.0 秒附 近までは写真濃度を增すが，それ以上は大した増加 が見られないととから实際には0.5〜0.6秒で撮影が 終了するととになる。

しているが，乙れは收収体の薄いアルミニュウに透過す る軟X線をも台んでいるものであり，実際に成人の胸部 撮影ではフィラメントの予熱時間を除き 0.5 秒以上はフ イルム上に大して黒化度を增していないことは鎖骨下の フイルム濃度を測定してみると大体 1.2 の付近で止まっ ている.

以上のことから蓄電放電式装置で拡大撮影を行うこと は撮影電圧が変化し，これに伴うバイアス電圧が変化し ないので撮影不可能であるとは言えない，2倍桩大撮影 程度の拡大率であれば蓞電放電式でも甚だしく解鋭度を 害した写真にはならない，限時装置を取付けることによ って任意に撮影電圧を上昇し適当な時間内で撮影を終る ようにして電荷の波尾截断を行えば，ますます撮影電圧 とバイアス至適電圧との関係は正碓になってくる。

\section{〔VI]撮 影 法}

以上の実験を基碟として私の日常行っている胸部搪大 撮影を述べる。

（1）増感紙：一般に M.S の増感紙が使用されているが 私は H.S 使用している。このことに就いては実験の 結果からではなく出来るだけ管電圧を下げ総ての電気的 条件を容易に且つX線管焦点の破壊防止を考えてのとと からであるが，フィルムの感度の上昇と共に解鋭度のよ い増感紙にかえる予定である。

(2) 管電在 : $60-70 \mathrm{kV}$ 電告調節はあまり小きざみには していない，バイアス至啇電在との関係もあり約 $3000 \mathrm{~V}$ の変化を階段的行っている。

(3) 管電流：25mA 一定一般の脑部拡大撮影を行う場 合バイアス至適電生は $1750 ２ 000 \mathrm{~V}$ 付近であり，管電 流 $25 \mathrm{~mA}$ 通電するための加熱電流は約 5 アンペアであ 
って，との加熱電流であると若しバイアス回路に絶縁破 壊があった場合バイアス電在は鍳となる。撮影する瞬間 そとの事故起ったとしても 5 アンパアの加熱電流であ れば管電流は 450－500mAしか流れないためX線管焦点 破壊することはない。この安全限界内で撮影するため に $25 \mathrm{~mA}$ に定めた。

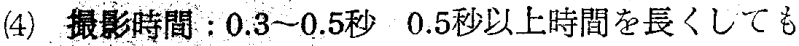
大して军真効果は望めないので，それ以上にはしていな い.出来るだけ短時間としてボケを少なく止めることに してァ.

(5) 撮影距離 : 焦点、つイルム間距離を $150 \mathrm{~cm}$ としてそ の中で任密の距離に被写体をおさ振影をしているが大体

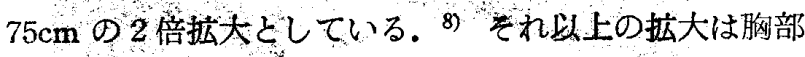
の場合あまり意味がないと言われているし，又実際的に みても拡大と其けボケも増大し診断に支障が出てくるの で行っていた

（6）撮影要領 ：桩大撮影を行う場合，常に注意している ことは如何に鮮鋭度のよい写真を得るかである．X楾写 真のボケは誤診をまねく慮れがある．即ち輪郭のハッキ リしない朦朧とした陰影ははたして病柴そのものの性質 か, 或いは拉大による幾何学的のボケなのか判定に苦し むよーとな。直接撮影フイルムや拡大写真の肋骨前後 の骨梁の鮮鋭度を参考にしているが，より鮮鋭な写真を 撮ることに努めている。

その方法として最も大切なことはX線管を傾斜させ焦 点の縦の長さを縮少させる場合の利用線錐を焦点面に対 して鋭角のとてろを使用するためにあるが，あまり焦点 平面に近い鋭角のとしろを用うると黒化度は甚だしく減 ずる。そこで適当なとてろを求めるために先ずX線管を 傾斜させ $150 \mathrm{~cm}$ の距離にリーダー撮影台をおきフイル ム取枠の固定部に増感紙の古い廃品を立てかけ $75 \mathrm{~cm}$ 距 離にもう一つの撮影台を置き撮影する目的の大きさを示 す針金杂を付図第 13-1のように取付け，X線室を暗く し X線管放射口濾過板を除きフイラメントを点火すると 針金劦は増感紙上に 2 倍に拡大投影されるのでそれに増 感紙（取枠）の位置を正確に合せ，次ぎにX線管放射口 に濾過板を覆い撮影電圧で充電を行うと焦点よりのX線 強度分布が増感紙上に映ずるので焦点の利用角度を知る ことが出来る.

この実験の後に患者の撮影目的部位を針金枠に合せ付 図第 13-2のようにして撮影を行うと殆んど矢敗のない 桩大撮影力泏来る.

この撮影準備があるため亿当療養所では拡大撮影は週 一度日起定めて行っている。
附図第13-1 撮 影 广j 法 (1)

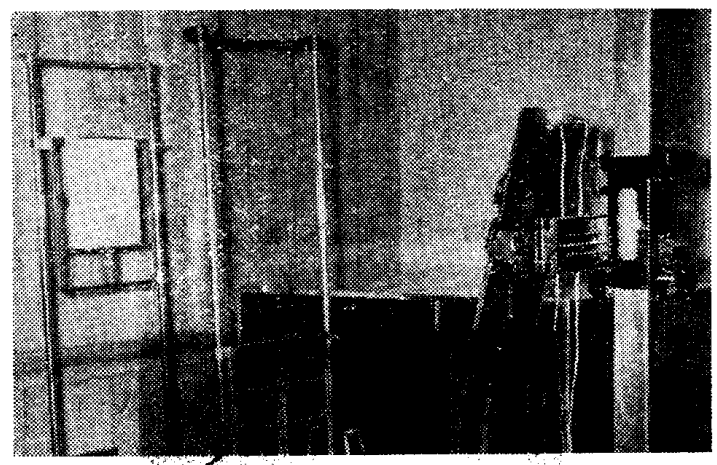

子め針金で撮影部位の大きさを示す粋を作り，之れ を増感紙上に投影して正確飞位㯰をX線管傾斜角度 を測つておく。 附図第13-2 撮 影 方 法 (2)

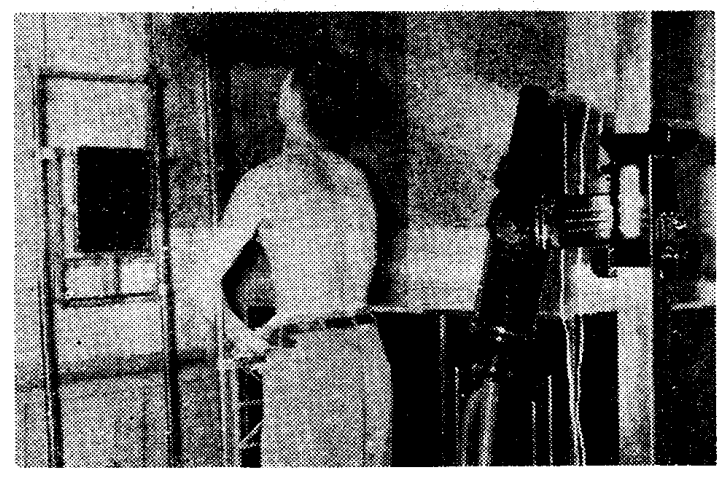

又肺結核の病集は殁んどが肺肺上野にあるため心藏博 動によるボケはあまり目立たないし，摄影の場合は患者 に呼吸停止要領を練習させ動摇，呼吸によるボケに注意 している.

フイルムは 6 ッ切又は 8 ッ切を使用し胡の部分撮影を 行っているが，その拡大写真は付図第 14-1.2 に示した。

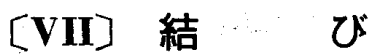

$\mathrm{X}$ 線桩大撮影は一般に変圧器方式の装置を用いて行わ れているが私は蓄電放電式装置（KCD-A型）を改造し てX線拡大撮影を可能にしたのでここに報告した。即ち （1）陽極接地方式学陰極接地方式に改造し陽電荷を X線 管に印加した。

（2）陰極接地方式のため微小焦点に電子を集束するのに 総ての酎压は単にバイアス電在のみですみ電気的操作が 簡単になった。

（3）微小焦点の4 倍㹡大写真像によって焦点の変化や大 きさを容易に知ることが出来た。

（4）微小焦点の解像力により測定法には 200 メッシュの 金網を用い，乙れが 3 倍拡大までに解像された。

(5) 管電圧 $60 \mathrm{kV}$ の場合バイアス至適電圧は $1750 \mathrm{~V}$ 付 近にあり，その微小焦点の大きさは $0.2 \mathrm{~mm}^{2} \sim 0.3 \mathrm{~mm}^{2}$ 
附図第14-1 㹡大撮影写真 密着

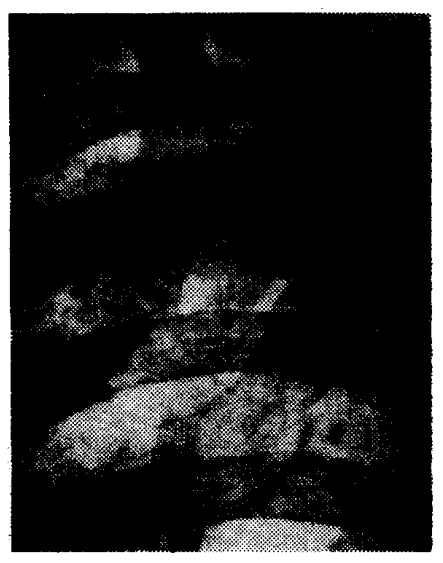

2 倍 拡大

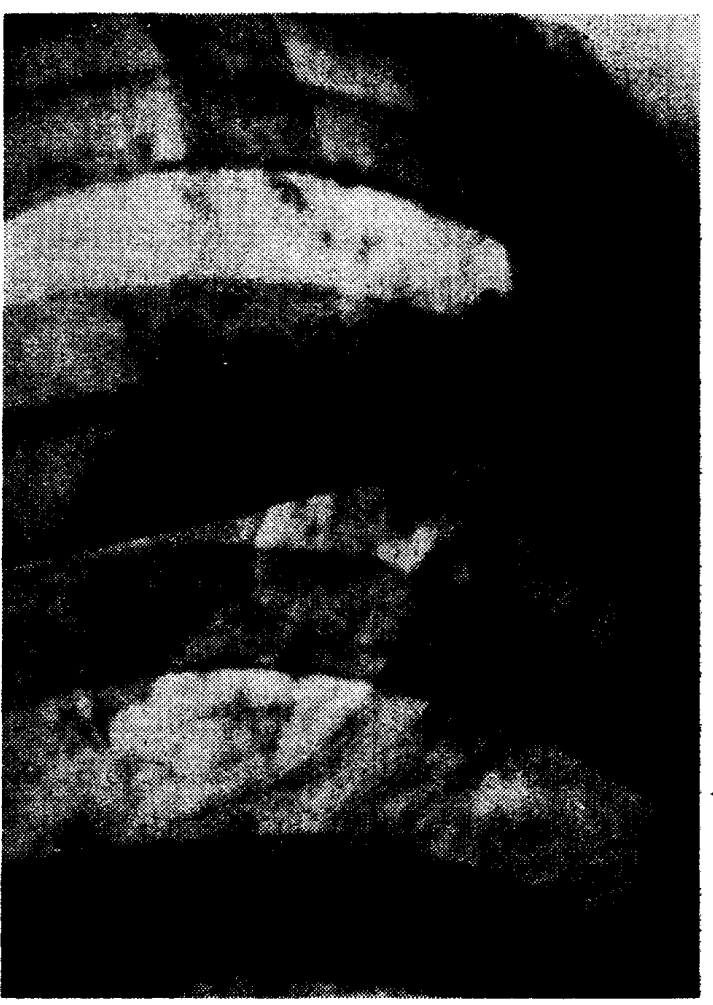

2 倍搪大

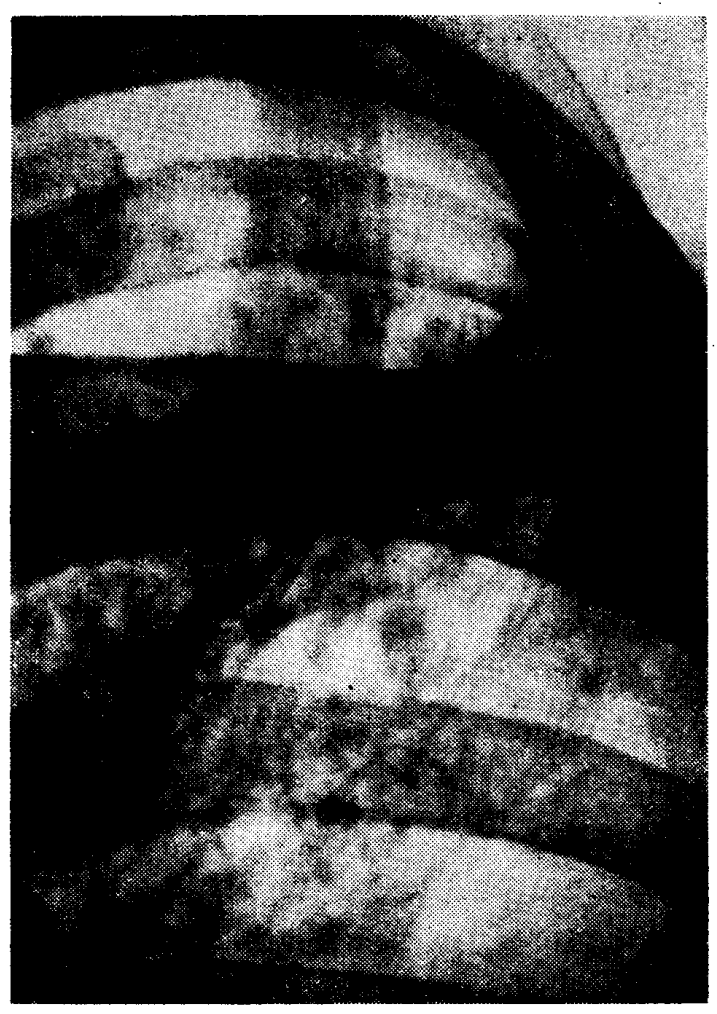

附図第14-2 拡大撮影写真

密着

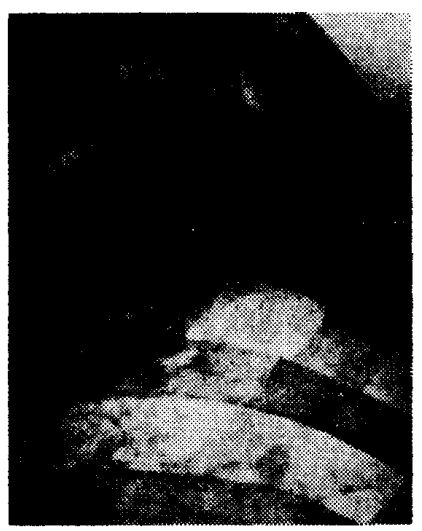


の範囲である。

(6) 管電圧 $60 \mathrm{kV}$ ，バイアス至商電圧 $1750 \mathrm{~V}$ で放電を行 つた場合，管電圧が $45 \mathrm{kV}$ 付近まで降下すればバイアス 電圧の遮蔽グリット効果によって管電流は流れなくな る.

（7）蓄電放電式の場合バイアス至適電圧は充電々圧に合 せておけばよい。

（8）管電圧 $60 \mathrm{kV}$, 蓄電器容量 $1.0 \mu \mathrm{F}$ バイアス至適電圧 $1750 \mathrm{~V}$ ，管電流 $25 \mathrm{~mA}$ で放電を行うとその放電時間は 約 1.0 秒であり，脍部撮影を行い有効撮影時間を測定し たら約 0.5 秒であった。

（9）限時装置を付属させ任意の時間で放電し残溜電荷の 波尾截断を行なうととが出来るので蓄電放電式装置の拡 大撮影には限時装置は必要である。

(10) 胸部 2 倍抎大撮影の条件は管電圧 $60 \sim 70 \mathrm{kV}$ ，管電 流 $25 \mathrm{~mA}$ ，撮影時間 $0.3 \sim 0.5$ 秒，撮影距離 $150 \mathrm{~cm}$ であ る

又近く東茫より $\mathrm{SDO}-10 \mathrm{~kW}$ と $4 \mathrm{~kW}$ の二重焦点拨 大撮影用のX線管が到着するので，乙れを用いて詳紐に 実験並に拡大撮影を行いあらためて報告する予定である が一応現在までの実験及び胸部拉大撮影結果を報告し諸 賢の御批判を仰ぐ次第である。

終りに臨み御指導御校閲を睗りました恩師北大山田教 授, 若林教授, 河村助教授並びに当癔養所長近藤博士, 医務課長岩田博士の諸先生に深謝します，又終始御助言
御指導下さいました石村器械製作所石村富明氏，渡辺範 夫氏，研究用フイルムの提供をいただきました富士フィ ルム札幌出張所長牛田昇氏亿敬意を表します。

\section{交}

1）高橋信次，小見山喜八郎：日放 14, No.医誌 Vol. 3. 1954.

2）田部貞夫：X線管研究 No. 3, 43, 1954.

3）高橋信次, 小見山喜八郎：さくら Xレイ写真研究 No. 12, 1, 1955.

4）小見山喜八郎：日放医誌 Vol. 14, No. 1954 .

5）深津久治，三島初太郎：東芝 X 線資料 No. 11，9， 1955.

6）高橋信次：日本医事新報 No. 1590, 1954.

7）足立 忠：日本医事新報 No. 1656, 1956.

8）小見山喜八郎，藤巻正裕：日放医誌 Vol. 15, 1028, 1956.

9）古谷鉄夫，三谷幸夫：日放技誌 Vol. 11, 88, 1956.

10）西场清美：東芝 $X$ 線資料 No. 1, 5, 1951.

11）中堀孝志外二名：島津評論 Vol. 7. 65, 1959.

12）江藤秀雄：日本臨床 Vol. 13, 147. 1955.

13）高橋信次，田中正道：日放医誌 Vol. 15. 838, 1955.

14）小見山喜八郎：日放医誌 Vol. 15, 81, 1955.

15）田中正道: X線管の研究 No. 1, 43. 1951.

16）吉田三毅夫 : 日放医誌 Vol. 15, 91, 1955. 